\title{
Farmer Organization, Collective Action and Market Access in Meso-America
}

Jon Hellin, International Maize and Wheat Improvement Center (CIMMYT)

Mark Lundy, International Center for Tropical Agriculture, (CIAT), and

Madelon Meijer, Food and Agriculture Organization (FAO)

Research Workshop on Collective Action and Market Access for Smallholders October 2-5, 2006 - Cali, Colombia

The CGIAR Systemwide Program on Collective Action and Property Rights (CAPRi) is an initiative of the 15 centers that belong to the Consultative Group on International Agricultural Research. The initiative promotes comparative research on the role played by property rights and collective action institutions in shaping the efficiency, sustainability, and equity of natural resource systems. CAPRi's Secretariat is hosted by the International Food Policy Research Institute's (IFPRI) Environment and Production Technology Division (www.ifpri.org).

CAPRi Working Papers contain preliminary material and research results and are circulated prior to a full peer review in order to stimulate discussion and critical comment. It is expected that most Working Papers will eventually be published in some other form, and that their content may also be revised. http://dx.doi.org/10.2499/CAPRiWP67.

Copyright (c) October 2007. International Food Policy Research Institute. All rights reserved. Sections of this material may be reproduced for personal and not-for-profit use without the express written permission of but with acknowledgment to IFPRI. To reproduce the material contained herein for profit or commercial use requires express written permission. To obtain permission to reprint, contact the IFPRI Communications Division at ifpri-copyright@cgiar.org.

CGIAR Systemwide Program on Collective Action and Property Rights (CAPRi) C/O INTERNATIONAL FOOD POLICY RESEARCH INSTITUTE 


\section{ACKNOWLEDGEMENTS}

The authors are very grateful to the Food and Agriculture Organization of the United Nations (FAO) for funding the research in Mexico and Central America. The authors would also like to thank two anonymous reviewers as well as Sophie Higman and John Dixon for invaluable comments on earlier versions of this paper. 


\begin{abstract}
The global agricultural economy is changing. Commodity prices are declining, and producers increasingly supply complex value chains. There is growing interest in how farmers can benefit from emerging market opportunities. Farmers are encouraged to produce high value crops and engage in value-adding activities such as agro-processing. Farmer organization and collective action are often seen as key factors in enhancing farmers' access to markets. Often too little attention is directed at a) the most appropriate types of organization, b) whether the public and/or private sector is best placed to support their formation, and c) the conditions necessary for ensuring their economic viability. This paper reports on research in Mexico and Central America that explored these issues for commodity maize and high value vegetables respectively. The benefits of farmer organization are more evident in the vegetable sector characterized by high transaction costs associated with market access. The research suggests that farmer organizations established by and directly linked to supermarkets may be more economically sustainable as opposed to organizations supported by non-governmental organizations. However, the most representative vegetable producer organizations in both Honduras and El Salvador include fewer than 5 percent of total horticultural producers. This is due to producer organizations' limited business skills and non-replicable organizational models for linking producers to markets. There is less incentive for maize farmers to organize themselves to access output markets as the transaction costs associated with market access are relatively low: there are so many buyers and sellers that farmer organizations would have little impact on, for example, prices. The benefits of farmer organization are clearer when it comes to accessing credit, seed, and fertilizer. Farmer organization is a critical factor in making markets work for the poor particularly in high value products, but the role and timing of the substantial public and private investment needed to establish and maintain these organizations is poorly understood.
\end{abstract}

Keywords: smallholder farmers, maize, high value agricultural products, Mexico, Central America, business development services, value chains, pro-poor growth 


\section{TABLE OF CONTENTS}

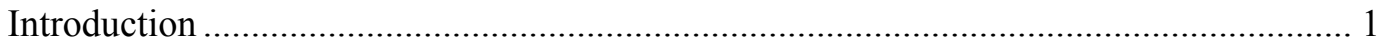

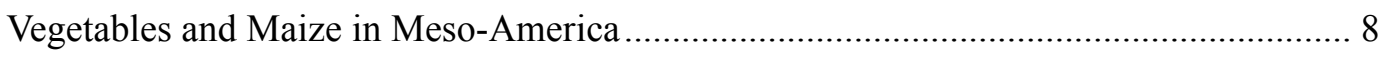

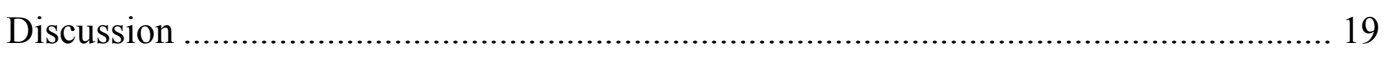

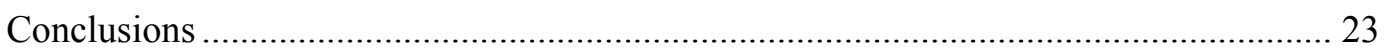

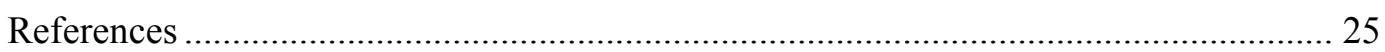




\title{
Farmer Organization, Collective Action and Market Access in Meso-America
}

\author{
Jon Hellin, ${ }^{1}$ Mark Lundy, ${ }^{2}$ and Madelon Meijer ${ }^{3}$
}

\section{INTRODUCTION}

\section{Making markets work for the poor}

One of the criticisms of the conceptualization and application of livelihood approaches to development thinking is the lack of emphasis on markets and their roles in livelihood development and poverty reduction (Dorward et al. 2003). This may result in a failure to identify and act on livelihood opportunities and constraints arising from critical market processes, and institutional issues that are important for pro-poor market development. Within policy, research, and development agendas, there has been a reemergence of interest in agriculture and pro-poor growth ${ }^{4}$ in rural areas. Featuring high on the development agendas is enhancing farmers' access to markets especially through the production of high value agricultural products (e.g. fruits, vegetables, poultry and fish), by engaging in value-adding activities such as agro-processing (Gulati et al. 2007; Miehlbradt and McVay 2005) and by group marketing.

The interest in making markets work for the poor is partly in response to changes in the global agricultural economy that are providing rural producers with both new challenges and opportunities. These changes include trade liberalization, increasing food safety and

\footnotetext{
${ }^{1}$ Jon Hellin, International Maize and Wheat Improvement Center (CIMMYT), Poverty Specialist, Mexico, D.F., Mexico.j.hellin@cgiar.org.

${ }^{2}$ Mark Lundy, International Center for Tropical Agriculture (CIAT), Specialist in Rural Agroenterprises. Coordinator of the Project's activities in Central America and the Caribbean. Cali, Colombia. M.lundy@cgiar.org

${ }^{3}$ Madelon Meijer, Food and Agriculture Organization (FAO), Economist Associate Professional Officer/ ESAE. Rome, Italy. madelon.meijer@fao.org.

${ }^{4}$ Pro-poor growth is growth that is good for the poor (DFID 2004). One definition of pro-poor growth considers only the incomes of the poor and the extent to which growth is 'pro-poor' depends on how fast the incomes of the poor are rising. Pro-poor growth can be seen as the average growth rate of incomes of poor people.
} 
quality standards, and shifts in food consumption patterns (Narayanan and Gulati 2002:11). One challenge that farmers face is the general long-term decline in the real price of commodities, a trend that has been going on for over two decades and has been in part linked to the structural adjustments and cuts in fiscal deficits under the umbrella of the Washington Consensus. During this period, many developing countries dismantled state marketing boards that had previously exerted monopoly control over domestic trade and prices for agricultural commodities. One consequence was that farmers were no longer compelled to sell at prices set below the value of their produce on world markets. However, farmers had often relied upon the same marketing boards for accessing inputs such as credit and fertilizer as well as extension and training. In many cases, neither government nor the private sector has taken on these roles, and farmers in many developing countries have faced increasing prices for inputs and declining access to effective technical services.

On the other hand, new market opportunities have arisen with this rapid growth in 'global markets' for products based on long and integrated supply chains (ODI 2003; Kydd 2002; Barghouti et al. 2004). Due to a rapid growth in demand from expanding urban populations in developing countries, food systems can no longer be viewed simply as a way of moving basic staples from farm to local plates. Producers now often supply long and sophisticated market chains, and market processed and branded products to mainly urban consumers. This is particularly the case with changes in the retail system due, partly, to the growth and increasing concentration of supermarkets (Reardon 2005; Hu et al. 2004; Reardon and Berdegué 2002).

In general, there has been a trend away from supermarkets occupying only a small niche in capital cities and serving only the rich and middle class, to spreading well beyond the middle class in order to penetrate deeply into the food markets of the poor (Reardon 2005). To ensure quality and consistent supply of perishable goods, supermarkets are pushing the food marketing system toward more vertical coordination, allowing retailers to standardize quality, improve bargaining power, and achieve economies of scale (Gulati et al. 2007; Boehlje 1999; Echánove and Steffen 2005). The growth of supermarkets has seen a shift from exclusive reliance on spot markets toward the use of specialized wholesalers (Berdegué et al. 2007; Shepherd 2005), contracting (Stockbridge et al. 2003; Key and 
Runsten 1999), and the growth of private quality and safety standards as well as private enforcement of public standards (Pingali et al. 2005).

The growth in supermarkets and other retail outlets has been mirrored by an increase in demand for high value agricultural products (HVAPs) such as fruits and vegetables, poultry, and fish. High value markets are attractive to farmers because the net benefit of selling to supermarkets relative to selling to traditional markets tends to be much higher in niche/quality products ("non-commodities") compared to bulk, mass commodities (Reardon 2005; Singh 2005). The challenge for farmers is that high-value crops are often perishable and are typically associated with high transaction costs (Pingali et al. 2005). For the smallholder farmers who do manage to enter these more lucrative markets, many find it difficult to stay in it due to the high risks and cost of cultivation involved.

The vertical coordination associated with modern retailing has had a profound impact on smallholder farmers, particularly due to the shift towards specialized/dedicated wholesalers who are usually more responsive to quality, safety, and consistency requirements of supermarkets: smallholder farmers are challenged to supply consistent volumes of high quality. Obviously, not all value chains supply supermarkets, but as Reardon and Flores (2006) have pointed out, traditional food industry firms will almost certainly need to alter their procurement practices from farmers in order to cut costs and improve quality so as to compete with the supermarkets. The result is that rural producers may well be affected both in an urban market progressively dominated by supermarkets as well as at the traditional retail and wholesale segments that compete with supermarkets.

Smallholder farmers often cannot meet stringent food safety and quality control requirements; they are seldom able to provide standardized products on a continuous basis as is often demanded by buyers, and they often lack market information (Gulati et al. 2007). In the context of making markets work for the poor, strategies are, therefore, needed that enable producers to diversify or upgrade production, and to compete more effectively in markets where they have advantages. This will involve strengthening competitiveness in the enterprises, value chains, and wider business environments on which rural producers depend. Key issues include:

- Building linkages between small-scale rural producers, value-added processing firms, buyers in growing urban markets, and suppliers of critical inputs; 
- Supporting small-scale producers to associate, collaborate, and coordinate to achieve economies of scale in their transactions with input suppliers and buyers;

- Making channels of information (e.g. about product specifications, market prices) and other business services accessible to rural producers;

- Enabling rural producers to understand and better satisfy the product, process, or delivery standards required by buyers in urban markets;

- Diversifying and raising levels of knowledge and skills in agricultural production and post-harvest processing that adds value to products;

- Making relevant financial services that enable investment in diversification or upgrading available to rural producers.

The above imply the need for close linkages between farmers, processors, traders, and retailers to coordinate supply and demand (Gulati et al. 2007), and to access key business development services (BDS) such as market information, input supplies, and transport services. Mechanisms for delivering these key services can differ substantially, and there is an on-going debate about the role of the public and private sectors in providing BDS (Miehlbradt and McVay 2005). Traditionally, BDS to small enterprises (including agricultural value chains) have been delivered with the support of donor and government subsidies primarily to achieve national goals, such as higher employment, rapid industrialization, and better export competitiveness in international markets (Marr 2003). Critics point out that public provision of BDS distorts market prices (as services are delivered, in most cases, in a highly subsidized manner, prices are lower than those determined by market forces) and undermines the provision of BDS by the private sector (Hitchens et al. 2004). Furthermore, public interventions were not seen as sustainable because of their costs.

In recent years, there has been a shift in thinking from subsidized supply-led BDS provision to market-determined demand-driven services, where both the demand and supply sides of the market are developed. The private sector is seen as the driving force behind a system of payment for services in a competitive and evolving market. In the majority of cases, however, the private sector has proven incapable and/or unwilling to replace previous state services due to high transaction costs, dispersed clientele, and low (or non-existent) profits (Lundy et al. 2002). In response, policy makers and development practitioners are increasingly supporting small-scale producers to associate, collaborate, and coordinate in 
order to access BDS and achieve economies of scale in their transactions with input suppliers and buyers: collective action and producer organizations are, therefore, not surprisingly one of the foci of the pro-poor market approach (e.g. DFID 2005).

\section{Farmer organization}

In this paper, we use the term collective action in the sense of "voluntary action taken by a group to achieve common interests" (Meinzen-Dick and Di Gregorio 2004). Collective action can therefore exist in the absence of farmer organization. We see farmer organization as a more formal expression of collective action. Farmer organizations can provide farmers with many services that are critical to their success in accessing markets (Table 1). There are many success stories of farmer organizations leading to active and effective farmer participation in value chains, e.g. in the case of coffee producers in South America (Hellin and Higman 2003). One of the better known is the milk industry in India: more than 70 percent of India's milk is produced by households who own only one or two milk animals, and these producers form part of a nationwide network of dairy cooperatives. (FAO 2004:24).

Table 1. Services provided by farmer organizations

- Marketing services (input supply, output marketing and processing, market information)

- Facilitation of collective production activities

- Financial services (savings, loans and other forms of credit)

- Technology services (education, extension, research)

- Education services (business skills, health, general)

- Welfare services, (health, safety nets)

- Policy advocacy

- Managing common property resources (water, pasture, fisheries, forests)

Source: Stockbridge et al. 2003

The enthusiasm for farmer organizations has, however, at times obscured the fact that the process of establishing viable organizations is not a simple one. It is often a challenge to 
establish the rules on which farmer organizations are based; to secure commitments on the part of the group members to abide by collectively-agreed rules; and to monitor and enforce compliance with the rules. In some cases, the establishment of farmer organizations incurs transaction costs which, if too high, may mean that farmers are better off not organizing (Stockbridge et al. 2003). Furthermore, successful association requires management and entrepreneurial skills, i.e. 'soft' assets that many small producers with little education are less likely to have (Pingali et al. 2005).

Stringfellow et al. (1997) identify three key factors that determine whether or not successful farmer cooperation for marketing is likely to take place: a) a match between the existing skills/experience of members and what is required to undertake joint activities; $b$ ) internal cohesion and a membership driven agenda; and c) successful, commercially oriented, integration of the organization into the wider economy. The dilemma for development practitioners is that the conditions for successful cooperation (minimum levels of education, skill, financial capacity, etc) tend to work against successful cooperation by the poor, especially the poorest of the poor (Hulme and Shepherd 2003).

There are, hence, numerous examples of attempts to foster farmer organizations foundering on the rocks. In Zimbabwe, local farming groups that had been established to access inputs and/or market outputs had largely disintegrated partly because there was considerable mistrust between farmers in relaying useful market information (Masakure and Henson 2005). One of the authors has experience from Cajamarca in Peru where a lack of trust between farmers stymied attempts to encourage farmer collaboration. Milk producers could receive a reasonably good price for their milk if they sold it to the local factory. The factory collected milk from the surrounding villages but only from producers who sold more than 3 liters of milk daily. So much mistrust existed that producers who were unable to meet this minimum volume threshold were not prepared to pool their daily milk production so as to allow them to sell to the factory. These producers had little alternative but to sell milk at a lower price to local cheese makers.

Berdegue (2002) also reports on problems faced by Associative Peasant Business Firms (EACs) in Chile where close social relations prevented an EAC from enforcing rules 
of sanctions, due to the fear of alienating friends, neighbors, or members of the same families. In Mexico, many collective and cooperative rural organizations, including the ejido ${ }^{5}$ system, have a history of being used for political ends and subject to manipulation by corrupt leaders, or have failed because of interpersonal jealousies and mistrust (Key and Runsten 1999). There is also the issue of trust between producers and buyers in both contract farming and other situations: Rehber (2004) reports that in Turkey, when the spot market prices were higher than the contract prices, small-scale vegetable producers were accused of selling their goods produced under contract on the open market. When the contract price is higher than on the open market, farmers try to supply more products to the contracting processor, having obtained produce from other farmers who are not included in the contract.

A great deal of public (and private) money has been invested in establishing farmer organizations with mixed results in terms of the number of beneficiaries and the sustainability of the organizations (Berdegue 2001; Camacho et al. 2005). All too often the process leading to farmer organization is instigated by outside agents such as government and NGOs, and in some cases the private sector (e.g. dedicated wholesalers supplying supermarkets). When government and/or NGOs are involved, there is a danger that at the first signs of financial trouble, the outside agencies will be tempted to bale out the farmer organizations and by so doing externalize some of the organization's costs (Berdegué 2001). This partly isolates the farmer organization from its market context and may begin a vicious circle of more subsidies having to be poured into the organization.

As part of new thinking on the role of the state and private sector in pro-poor markets and growth, decisions have to be made as to whether the private or public sector should pay for and support the establishment of farmer organizations. There is a need, therefore, to understand better when farmer organizations make sense, when they do not, and how they can best be established and maintained. Specifically, more information is needed on: i) the most appropriate types of organization if any; ii) whether the public and/or private sector is best placed to support their formation; and iii) the conditions necessary for ensuring their

5 There are two kinds of ejidos: the more common individual ejido, in which land tenure and ownership are legally vested in a community, but plots of land are allocated on a semi-permanent basis among individual ejido members; and the collective ejido, in which land resources are pooled for collectivelyorganized production. 
economic viability. We explore these issues in the context of high-value vegetables in Honduras and El Salvador, and commodity maize in Mexico.

\section{VEGETABLES AND MAIZE IN MESO-AMERICA}

\section{Introduction to case studies}

Meso-America includes southern Mexico and Central America and the predominant farming system found in the upland areas is maize-beans. While these two crops provide some livelihood security for millions of smallholder farmers, extensive poverty is found throughout the system (Dixon et al. 2001). With commodity prices declining, farmers' participation in high value and/or value-adding activities offer one of the few agriculturalbased pathways to reduced poverty and increased livelihood security. Development agencies in Mexico and Central America have actively promoted the expansion or establishment of higher value crops, such as fruit and vegetables, to complement existing food security options such as maize and beans (Hamilton and Fischer 2003).

In Meso-America, the trade in vegetables has increased substantially since the early 1980s. Urbanization, increasing incomes, and the resulting demand for vegetables are the main drivers for the expansion. Trade is both intra-regional and international: since the mid1980s, the export trade in fruits and vegetable in Central America grew by 330 percent (Reardon and Flores 2006). Recently this process has been accelerated through an increasing focus on the use of fresh or healthy ingredients by urban populations. In many cases, this has been actively promoted by the supermarkets themselves through the use of various promotional strategies focused on increasing overall vegetable consumption.

The research on vegetables reported in this paper took place in Honduras and El Salvador. Both countries possess relatively well-defined areas of smallholder vegetable production based on land tenure patterns and existing natural advantages presented by hillside environments. Smallholder vegetable production in hillside environments benefits from a slightly lower incidence of pest and disease problems and improved access to yearround water supplies. It is important to note, however, that medium to large-scale vegetable production also occurs in lower lying valleys in both countries. Vegetable production in 
these valleys was not included in the current study principally because producers there tend to be large-scale commercial operations.

The more traditional vegetable market channels in Honduras and El Salvador are comprised principally of networks of informal traders that link individual smallholder producers with regional and national markets. This market channel is characterized by cash payments and limited quality demands. The final product is mainly sold in urban wholesale markets although some traditional traders have developed the necessary skills and knowledge to sell a portion of their produce to specialized wholesalers and, in some cases, to supermarkets and restaurants directly. The modern retail system is comprised of diverse types of farmer organization ranging from formal associations to the lead farmer model linked to specialized wholesalers and/or directly into supermarkets, restaurants, and hotels.

The vegetable production chain in Honduras and El Salvador operates within a context defined by public policies, access, and control of infrastructure and environmental considerations. Of relevance to the present study are existing public policies in both Honduras and El Salvador focusing on the agricultural sector. In addition to existing national policies focused on rural development and the horticultural agri-food chain in particular, both Honduras and El Salvador are signatories of the recently approved Central American Free Trade Agreement (CAFTA) with the United States. Initially, actors from the horticultural agri-food chains in both countries felt that the approval of CAFTA was a step forward in terms of competitiveness. However, CAFTA also opens the door for potential agricultural imports, including vegetables, from Mexico and the United States itself. While the full impact of CAFTA remains to be seen, this treaty more than any national level policy will define the future for many horticultural producers in the region.

In 2005, the International Center for Tropical Agriculture (CIAT) with the support of the Food and Agricultural Organization of the United Nations (FAO) and in collaboration with two development agencies ${ }^{6}$ undertook a study of how changes in markets affected smallholder vegetable producers in Honduras and El Salvador and identified strategies to

\footnotetext{
${ }^{6}$ The Agropyme Project of Swisscontact in Honduras and the El Salvador office of Catholic Relief Services.
} 
facilitate the participation of smallholder vegetable producers in the value chains linked to local supermarkets. One area of work was on the role of farmer organizations.

While growing vegetables may offer some farmers a pathway out of poverty, millions of smallholder farmers in Meso-America still rely on maize for their livelihood security, and none more so than in southern Mexico. Mexico is the center of origin of maize, as well as being a center of maize diversity. Maize has been cultivated for approximately 6,000 years in Mexico, is a staple food crop in the region, and is believed by many indigenous groups to represent the origin of life itself (Long and Villarreal 1998). Maize in Mexico is used for two main purposes: white maize is used for direct human consumption and yellow maize for indirect consumption as a component of livestock feed (most in poultry, egg, and pork production) (Sain and Lopez-Pereira 1999). Secondary uses include maize stalks for fencing, leaves for fodder, and husks for wrapping traditional foods such as tamales.

The North American Free Trade Agreement (NAFTA) signed in 1994 has had a major impact on maize producers in Mexico. Whereas the Mexican government provided major support to maize producers throughout much of the $20^{\text {th }}$ century, NAFTA signaled a change of direction: while support still exists, the Mexican government has implemented changes that are designed to raise the efficiency and competitiveness of Mexican agriculture. Government policies extend not only to the prices that Mexican farmers receive for their crops (formerly government regulated, but now subject to only minimal and decreasing cushioning), but also to the programs governing how farmers access technical extension, agricultural inputs, and credit.

The research reported here is part of a research project on the impact of markets on farmer management of maize conducted by the International Maize and Wheat Improvement Center (CIMMYT) and FAO. Research took place in the Frailesca region in the southern Mexican state of Chiapas. La Frailesca occupies an area of $2631 \mathrm{~km}^{2}$ and is situated in a valley at an altitude of $600 \mathrm{~m}$ with surrounding mountains reaching an elevation of $2000 \mathrm{~m}$ (Erenstein et al. 1998). Farming activities in Chiapas are both subsistence- and marketoriented, and the agricultural sector has received strong support from state and federal governments. Maize is the dominant crop, and cattle-ranching is a complementary activity: maize crop residues are an important source of forage in the dry season. La Frailesca 
produces large maize surpluses that are exported to other parts of Mexico, but maize production is still dominated by small-scale farmers (Flores et al. 2004).

The two case studies, therefore, represent two contrasting options for smallholder farmers in the Meso-American maize-bean farming system: diversifying into HVAPs and/or intensifying maize production and marketing. We look at the role of farmer organizations in these contrasting situations.

\section{Vegetables in Honduras and EI Salvador}

In Honduras and El Salvador, a methodology was used based on participatory value chain analysis. The research team analyzed the history of the value chains; the relationships between the chain actors; current and projected market conditions; the financial health and viability of the farmer organizations; and, finally, the development of strategies to improve the functioning of the value chains. The principal focus of this research was on the direct actors (producers, producer organizations, marketing and retail actors, and the final consumers) in the chain and their relationships with each other. This work was carried out through workshops, focus groups, and semi-structured interviews with key actors: individuals and groups of farmers, intermediaries, and supermarkets.

Vegetable producers were subdivided into three categories: individual smallholder producers, small producers organized into producer associations, and independent producers with a secure market. The focus of the study was on the second category, and research was directed at three formal producer organizations in El Salvador and two in Honduras (Table 2). These were the only formal producer organizations active in the supermarket channel for vegetables at the time of the study. An important caveat to this research is that while care was exercised to identify and study the most relevant and/or representative group of formal farmer associations in Honduras and El Salvador, Table 3 shows that the vast majority of vegetable producers are not members of any farmer organization. 
Table 2. Producer organizations included in the study

\begin{tabular}{llllll}
\hline Organization & Country & $\begin{array}{l}\text { No. of } \\
\text { farmers }\end{array}$ & $\begin{array}{l}\text { Annual } \\
\text { sales (1000s } \\
\text { USD) }\end{array}$ & Products & Market channels \\
\hline ACOPO & $\begin{array}{l}\text { El } \\
\text { Salvador }\end{array}$ & 23 & $140^{\mathrm{a}}$ & $\begin{array}{l}\text { Lettuce, baby } \\
\text { carrots, radishes }\end{array}$ & $\begin{array}{l}\text { Supermarkets, hotels and } \\
\text { restaurants }\end{array}$ \\
\hline AGROLEMPA & $\begin{array}{l}\text { El } \\
\text { Salvador }\end{array}$ & 70 & $177^{\mathrm{b}}$ & $\begin{array}{l}\text { Tomato, bell } \\
\text { pepper, } \\
\text { cucumber }\end{array}$ & $\begin{array}{l}\text { Supermarkets, hospitals, } \\
\text { processors and restaurants }\end{array}$ \\
\hline APRHOFI & Honduras & 110 & $184^{\mathrm{c}}$ & $\begin{array}{l}\text { Carrots, lettuce, } \\
\text { broccoli, } \\
\text { potatoes }\end{array}$ & $\begin{array}{l}\text { Specialized wholesalers, } \\
\text { supermarkets, restaurants and } \\
\text { wholesale markets }\end{array}$ \\
\hline COHORSIL & Honduras & 285 & $89^{\mathrm{c}}$ & $\begin{array}{l}\text { Tomato, bell } \\
\text { pepper }\end{array}$ & $\begin{array}{l}\text { Specialized wholesalers, } \\
\text { supermarkets, wholesale } \\
\text { markets and local markets }\end{array}$ \\
\hline PHOC & $\begin{array}{l}\text { El } \\
\text { Salvador }\end{array}$ & 143 & $96^{\mathrm{c}}$ & $\begin{array}{l}\text { Tomato, bell } \\
\text { pepper, } \\
\text { cucumber }\end{array}$ & $\begin{array}{l}\text { Supermarkets and farmers } \\
\text { markets }\end{array}$ \\
\hline
\end{tabular}

Source: Authors' calculations based on Agropyme (2005) and CRS (2005).

Data from 2003 including vegetable sales and other income (CRS 2005:28).

Average over the last three years (CRS 2005:31)

Annual sales calculated based on monthly averages (Agropyme 2005:34-37; CRS 2005: 36)

Table 3. Number of horticultural producers in Honduras and EI Salvador compared to total membership of farm organizations studied

\begin{tabular}{l|l|l|l}
\hline Country & $\begin{array}{l}\text { Total number of } \\
\text { horticultural } \\
\text { producers }\end{array}$ & $\begin{array}{l}\text { Total number of } \\
\text { members in producer } \\
\text { organizations }\end{array}$ & $\begin{array}{l}\text { Percentage of horticultural } \\
\text { producers in producer } \\
\text { organizations }\end{array}$ \\
\hline Honduras & $15.000^{\mathrm{a}}$ & 395 & $2.6 \%$ \\
El Salvador & $8.000^{\mathrm{b}}$ & 236 & $3.0 \%$ \\
\hline
\end{tabular}

Source: Lundy et al. (2006) based on Agropyme (2005) and CRS (2005).

Number of vegetable producers according to the National Agricultural Census of Honduras 1993.

Number of producers in the horticultural agri-food chain according to BMI/Technoserve 2004 (cited in CRS 2005:25)

Total number of producers involved in producer organizations focused on vegetable production for supermarkets in Honduras and El Salvador (Agropyme 2005; CRS 2005). 
The vegetable crops included in the study (see Table 2) are highly dynamic. For example, the annual consumption of tomatoes in El Salvador is nearly 80,000 metric tons. Of this total, 67 percent are sold through informal market channels, 11 percent through supermarkets, and the remainder is consumed by the institutional and processed food markets. Approximately 65 percent of all tomatoes consumed in El Salvador are imported from neighboring countries such as Guatemala and Honduras (Lundy et al. 2006). Consumption figures in Honduras are significantly lower than in El Salvador due to population and income differences between the two countries: 6,000 metric tons per annum, of which 25 percent is sold though supermarkets. In Honduras, tomato is seen as a high risk crop for smallholders, and only medium to large producers with significant access to capital can produce this crop successfully.

In both countries, the majority of tomatoes are sold loose, but there is an increasing tendency for specialized wholesalers and producer organizations to explore the possibility of selling pre-packaged trays. In addition, there are attempts at branding these products in both countries. The grades and standards that are applied to these products by supermarkets vary depending on, among other factors, the availability of the product in the market, the relationship with the supplier, and the going price.

The economic analysis focused on the distribution of returns on investment among actors along the value chain and the relative differences between diverse marketing channels. Chain dynamics during the period of study showed the relative proximity of prices among different value chain actors involved in diverse market channels. The local trader who buys at the field level is competing with the producer organization while the specialized wholesaler/supermarket channel competes with the traditional wholesaler in urban centers. Specialized wholesalers are able to demand a higher price from supermarkets for their products principally due to investments in refrigeration, grades and standards, and consistent supply.

Table 4 shows the distribution of the final consumer price among value chain actors for different vegetables in Honduras. It was not possible during the study to identify the net margins for supermarkets and specialized wholesalers. As a result, the apparent lion's share of the final consumer prize that they receive may not be entirely accurate due to the perishable nature of the products and other factors. During workshops with supermarket 
buyers in Honduras, spoilage of between 8 to 10 percent for tomato and peppers was considered average (Lundy et al. 2006).

Table 4. Distribution of final consumer price among value chain actors in Honduras

\begin{tabular}{|c|c|c|c|c|c|c|c|}
\hline \multirow[b]{2}{*}{ Variables } & \multicolumn{7}{|c|}{ Products } \\
\hline & $\begin{array}{c}\text { Tomato } \\
\%\end{array}$ & $\begin{array}{c}\text { Bell } \\
\text { pepper } \\
\%\end{array}$ & $\begin{array}{c}\text { Potato } \\
\%\end{array}$ & $\begin{array}{c}\text { Broccoli } \\
\quad \%\end{array}$ & $\begin{array}{c}\text { Lettuce } \\
\quad \%\end{array}$ & $\begin{array}{c}\text { Carrots } \\
\%\end{array}$ & $\begin{array}{c}\text { Average } \\
\%\end{array}$ \\
\hline Production costs & 15 & 22 & 24 & 15 & 17 & 17 & 18 \\
\hline $\begin{array}{l}\text { Farm to packing shed } \\
\text { transportation costs }\end{array}$ & 4 & 12 & 1 & 4 & 6 & 1 & 5 \\
\hline $\begin{array}{l}\text { Net farmer income for } \\
\text { sale to producers } \\
\text { organization }\end{array}$ & 20 & 0 & 24 & 14 & 18 & 12 & 14 \\
\hline $\begin{array}{l}\text { Transportation costs to } \\
\text { Tegucigalpa or San } \\
\text { Pedro Sula }\end{array}$ & 2 & 2 & 1 & 4 & 5 & 1 & 2 \\
\hline $\begin{array}{l}\text { Net producer } \\
\text { organization income for } \\
\text { sale to specialized } \\
\text { wholesaler in } \\
\text { Tegucigalpa or San } \\
\text { Pedro Sula }\end{array}$ & 4 & 3 & 3 & 1 & 2 & 5 & 3 \\
\hline $\begin{array}{l}\text { Gross profit for } \\
\text { specialized wholesaler } \\
\text { for sale to supermarket }\end{array}$ & 25 & 32 & 16 & 32 & 22 & 33 & 27 \\
\hline $\begin{array}{l}\text { Gross profit for } \\
\text { supermarket }\end{array}$ & 30 & 30 & 30 & 30 & 30 & 30 & 30 \\
\hline $\begin{array}{l}\text { Retail price paid by final } \\
\text { consumer }\end{array}$ & 100 & 100 & 100 & 100 & 100 & 100 & 100 \\
\hline
\end{tabular}

Source: Lundy et al. 2006

Table 4 shows the producer organizations' relatively low share in the final consumer price: in Honduras the figure was only on average 3 percent of the final price while in El Salvador (data not presented here) the figure was 6 percent. Reflecting on these results with 
members of the value chains, the question of the economic viability of existing producer organization models was raised. The combination of relatively low volumes of product and low margins means that many of the farmer organizations included in the study require ongoing subsidies to cover operational costs despite significant support from donor and development agencies over long periods of time.

The study also raises the question as to whether there are alternative forms for farmer organization that might achieve similar social and economic returns for farmers at a lower overall cost (see discussion). Another issue is whether the benefits of farmer organization come from improved access to inputs such as seed and credit rather than output value chains. CIMMYT and FAO's research in Mexico sheds some more light on this.

\section{Maize in Mexico}

In contrast to the research in Honduras and El Salvador, in Mexico the study has looked at both the input and output value chains and the role of farmer organizations in facilitating access to both. The methodology used by CIMMYT and FAO was based on a market mapping tool (Hellin et al. 2005) and consisted of a series of semi-structured interviews and focus group meeting with key informants along the maize seed input and grain output chains: seed companies, extension agents, producer groups, and purchasers of grain. The project is focusing on the use of largely qualitative tools in order to identify the following:

- Structure of the maize grain market and prices offered to farmers;

- Impact of maize grain markets on farmer decision-making vis-à-vis what types of seed to plant;

- Reasons why farmers choose particular seed (the seed's attributes, the existence of government subsidies for different seed types);

- Frequency with which farmers purchase seed;

- How farmers access inputs (seed, fertilizer, credit etc.) and sell their grain.

Farmer organization, albeit on an informal basis, is common when it comes to accessing inputs such as seed, fertilizer, and credit. This has to be put in the context of a plethora of government agricultural support programs over the last 30-40 years. These 
programs have tended to focus on the provision of inputs and have encouraged some degree of collective action and organization on the part of farmers. Prior to NAFTA, Mexico's maize production was controlled by La Compañia Nacional de Subsistencias Populares

(CONASUPO), the state trading agency which set the prices paid to farmers and also fixed consumer prices at a low level through a set of subsidies. CONASUPO was dismantled at the end of the 1990s, but state support to agriculture has continued. In general, farmers have formed organizations under two scenarios: firstly, to take advantage of subsidized extension advice and an associated agriculture technical package; and secondly, to access subsidized maize seed.

Since the mid 1990s, private extension agents known locally as despachos have provided technical assistance to smallholder farmers. The despachos do not work with individual farmers and, hence, farmers have to organize themselves into groups. The despachos assist farmer groups to access credit provided at low interest rates by Fideicomisos Instituidos con Relación a la Agricultura (FIRA), a government body dependent on the Bank of Mexico. FIRA lends money at low interest rates to a number of banks who in turn provide credit to farmers at lower interest rates than would be the case if the banks were lending their own money. The credit is tied to a government-subsidized technical package that includes a set of inputs: fertilizers, pesticides, herbicides, and seed (Flores et al. 2004).

The despachos make money by selling this technical package to groups of farmers. FIRA also subsidizes the producer groups so that they are better able to pay for the technical package that the despachos provide. FIRA reduces the subsidy on a sliding scale from 70 percent of the package in the first year to 20 percent in the fourth year. The subsidized system worked well for a number of years, but in recent years, maize has become less profitable, farmers have defaulted on their loans, and the banks became less interested in lending to farmer groups; consequently, the number of despachos has fallen, and it remains unclear whether this public/private extension provision will continue.

The despachos are one of the ways that farmers are able to access another critical input: subsidized maize seed. Farmers can access improved maize seed in a number of different ways: a) from the despachos, b) from the seed companies directly, and from c) from village shops that sell agricultural inputs. While traditionally farmers recycled their maize 
seed, many farmers also plant improved seed, much of which is subsidized by the Mexican government.

Maize germplasm can be classified into three broad categories: hybrids, open pollinated varieties (OPVs), and land races. The first two categories are improved maize varieties. Simply put, a hybrid is the result of crossing two inbred lines, while improved OPVs are populations that have been subjected to selection by breeders. If seed from a hybrid is replanted, it will not be as productive as the original seed and thus has to be purchased every season to maintain its high productivity. In contrast, seed from an OPV can be replanted usually up to three years without major drops in yield and, hence, can be purchased once every three years (Bellon et al. 2005). The third category also includes so-called creolized varieties: seed from improved varieties - hybrids or OPVs - that have been recycled for four or more years or purposely crossed with local landraces.

While there is some variation from year to year, in 2006 the government subsidy amounted to 300 Mexican pesos (US\$28) per bag of seed with a limit of two bags per farmer. Each bag contains enough seed to plant one hectare. Depending on the type of seed, the subsidy covers anything from 30-100 percent of the cost of the seed. The seed distributors, who represent the various seed companies including Pioneer and Monsanto, strongly prefer working with groups of farmers as it reduces their transaction costs.

While in theory individual farmers can access the subsidy, the process takes longer, and farmers have more chance of receiving subsidized seed if they are part of a group. Furthermore, farmers have to make a request for the subsidized seed to the Secretaría de Desarrollo Rural (SDR) (Ministry of Rural Development). Demand outstrips supply. According to the SDR, the seed subsidy in 2006 was sufficient to cover 20,000 bags of seed. In June 2006, just before the beginning of the planting season, farmer requests for subsidized seed had reached 36,000 bags. Farmers, seed distributors, and the government confirmed that farmers have more chance of receiving subsidized seed if they are part of a group.

On applying for the subsidy, farmers receive a voucher that can be used to purchase subsidized seed from the seed distributors. One seed distributor ${ }^{7}$ explained that he supplied

\footnotetext{
${ }^{7}$ During the semi-structured interviews in June 2006, all the seed distributors spoke openly to CIMMYT researchers on the condition of anonymity.
} 
over 800 bags of subsidized seed to one village. He did so because the farmers in the village in question were very well organized. He 'helped' them access the seed subsidy and, because of the volume of seed that they purchased collectively, he was able to offer them a further discount on top of the 300 pesos per bag subsidy.

The community of Roblada Grande illustrates the advantages of farmers selforganizing when it comes to seed purchase. In 2006 a group of farmers in Roblada Grande made a successful request to the government for just over 800 bags of subsidized seed. The organization decided to purchase seed of a high-yielding maize hybrid. Each bag of seed normally sells for 940 pesos (US\$ 88) but the farmers decided to buy seed from one distributor and managed to negotiate the price down to 860 pesos (US\$ 80). With the subsidy, farmers ended up paying 560 pesos a bag (US\$ 52). Furthermore, the seed distributor transported the seed to the community at no extra cost.

While there are clear advantages to farmer organization when it comes to accessing inputs, there are very few examples of maize farmers in La Frailesca working together to access maize grain markets. The Mexican government fixes the grain price that farmers receive. Farmers sell grain to buyers called bodegas who set up buying centers outside villages throughout La Frailesca. Farmers bring their grain to these centers and assuming that the grain meets certain quality standards, the farmers will receive from the buyer the price fixed by the government. The farmer is issued a document confirming the amount of grain that has been sold. The document subsequently enables the farmer to access a federal government subsidy which is in addition to the fixed price they receive for each ton of maize grain sold.

There is no differentiated market for maize, i.e. farmers receive the same price irrespective of whether the grain in question is a land race, OPV, or hybrid, as long as it meets the quality standard. Furthermore, there is no price differentiation for white or yellow maize (the vast majority of maize grown in Mexico is white maize). Furthermore, the transaction costs associated with market access are relatively low: there are many buyers and sellers for an undifferentiated product. Farmer organizations would have little impact on, for example, prices. Also, individual buyers have little incentive to support the establishment of farmer organizations as their share of the market is low. 
The only evidence of farmer organization for grain sales is among a handful of farmers who sell maize to Buenaventura, a big chicken producer in La Frailesca. The contracts are with both individuals and groups of farmers and deal with grain purchases only. Buenaventura tried to arrange contracts in terms of supplying inputs such as fertilizer, but the initiative broke down because so many farmers failed to repay the loans. Buenaventura also found that in 2005 there were several contract farmers who sold their grain to others. Farmers selling under contract to Buenaventura often received a price only marginally higher than that fixed by the government.

Semi-structured interviews and focus group meetings in four farming communities confirmed that collective action and farmer organization among maize producers in La Frailesca is largely confined to accessing subsidized seed and fertilizer along with extension advice. In none of the four communities did the farmers identify any advantages to establishing a farmer organization to sell grain. In three communities, farmers said that they had formed groups in order to access subsidized inputs such as credit, seed, and fertilizer.

\section{DISCUSSION}

The case studies from Central America and Mexico demonstrate the opportunities and challenges surrounding the establishment of farmer organizations. They also shed light on several key questions that need to be addressed:

-Who is going to make the investment to support the establishment of farmer organizations: the public and/or private sector?

-How do you try to ensure sustainability of the farmer organizations?

-What are the cost implications for the public and private sector?

Answers to these questions in turn highlight a number of policy issues that need to be considered when it comes to facilitating farmers' access to markets especially in light of a changing political climate which more readily recognizes the key roles that the public sector (along with the private sector) can play in contributing to agricultural development. 
In the case of vegetable and maize producers, it is very rare for farmer organizations to self-organize on a formal as opposed to an informal basis. More often than not, support is needed in the establishment and continued performance of farmer organizations. An example of this is COHORSIL, a farmer cooperative in Honduras that was founded in 1980 and traditionally focused on coffee production, processing and marketing. Faced with declining prices for coffee, the cooperative sought to diversify its activities. With Swiss funding, they branched into the production and marketing of fresh vegetables. COHORSIL developed a business plan and ensured that its members had access to seedlings produced in greenhouses, warehouse and packaging facilities, and marketing services. The cooperative directly supplies these services for a fee and has also established links with private service providers who offer specialised services such as soil analysis, technical assistance, and the design and installation of drip irrigation systems. Many of the cooperative members are able to produce vegetables that meet the quality demands of local supermarkets (Hellin et al. 2007).

COHORSIL sounds like a success story, and in many ways it is. But if these subsidies provided market access to a large percentage of smallholders, there would be a case for continuing public sector or donor support; however, this is clearly not the case: despite significant investments of time and financial resources, existing vegetable producer organizations in both Honduras and El Salvador encompass significantly less than 5 percent of total horticultural producers in each country. Possible causes identified for the situation include limited business skills within existing producer organizations, nonreplicable organizational models for linking small holders to dynamic markets (e.g. too costly in terms of time and financial resources with limited benefits), and a general uncertainty about the benefits that small holders can expect from the supermarket channel (Lundy et al. 2006).

The results from El Salvador and Honduras mirror those for vegetable producers in Nicaragua. Berdegué et al. (2007) calculated that through the new "business linkages" programs of donors in horticulture, some farmers were receiving (in terms of NGO project budget per farmer) about eight times more than the Ministry of Agriculture in Nicaragua spends per farmer. It is likely, therefore, that these programs will continue to be mainly for the elite of small and medium farmers and be un-replicable by governments and thus possibly not sustainable in the longer term (Reardon and Flores 2006). 
The research team in Central America also discovered that one of the problems is that very few of the development organizations that have facilitated the establishment of farmer organizations have a clear understanding of the costs and margins along the value chain. This sort of information is needed in order to help them make sure that the services provided are sustainable once development subsidies dry up. Many organizations do not know how much it costs to provide, for example, technical assistance nor have they incorporated it into the cost structures. These costs can be substantial: externally-supported farmer associations in Honduras, for example, cover between 57 and 84 percent of smallholder incorporation costs (technical and organizational assistance, infrastructure and working capital) with donor funding (Agropyme 2006).

In comparison, recent work in Honduras shows that lead farmer models promoted by dedicated supermarket wholesalers require lower external support but much higher investment from farmers (Agropyme 2006). These models are organic organizational structures that grow around producers who have shown the ability to meet supermarket quality and quantity demands. Supermarkets encourage lead farmers to organize and support their neighbors to meet these demands, with little investment beyond the incentive provided by market opportunities. The initial time and financial investment in lead farmer models is significantly lower than models promoted by development agencies. Lead farmer models cover 12 percent of smallholder incorporation costs (technical and organizational assistance) with donor funds (Agropyme 2006); this compares favorably with the 57-84 percent of costs referred to above.

The results from the vegetable sector in Central America contrast with the maize sector in Mexico. In terms of market access, the research suggested that the benefits of formal farmer organization are more evident in the vegetable sector characterized by high transaction costs associated with market access. In the case of a low-value commodity crops such as maize, there was practically no evidence that it was in farmers' interests to organize themselves for market sales. This was because the costs of organizing were not compensated for by any increased income generated through maize sales or facilitating access to markets. Farmer organizations only made sense when it came to improved access to agricultural inputs such as seed and fertilizer. Furthermore, in some cases these benefits could be secured 
through informal or even short-lived organizations, such as groups of farmers coming together to access the seed subsidy, rather than more demanding formal ones.

The case of maize in Mexico also demonstrated the difficulties in providing fee-based services at a large scale. The establishment of the despachos in La Frailesca was an attempt to set up a fee-based extension and technical service albeit one that was initially subsidized by the government. While some despachos remain active in the agricultural sector, their numbers are declining.

Results from Central America and Mexico mirror the situation in Chile and experiences in the Andes. In Chile, the government facilitated the establishment of Associative Peasant Business Firms (EACs, or Empresas Asociativas Campesinas) in order to bring about a change from individual primary production in the family farm to marketoriented collective action. Berdegué (2002) found that farmers' participation in EACs had no significant beneficial impact for farmers producing undifferentiated commodities such as potatoes or wheat that are sold on the spot or at wholesale markets. In Chile, it was only under certain market conditions that it made sense for small farmers to engage in collective action for accessing markets: the most successful ECAs were amongst producers of HVAPs as opposed to producers of commodities (Berdegué 2002).

In policy terms, there is a growing recognition and acceptance that there is a role for publicly-funded services. For example, the success of the Asian Green Revolution was partly based on comprehensive agricultural support policies (e.g. fixed prices, fertilizer subsidies, and credit subsidies) that have since been dismantled as part of the structural adjustment policies of the 1980s and 1990s (Ellis and Harris 2004). This had led Dorward et al. (2004) to question the extent to which "policy changes of liberalization and withdrawal of the state removed from the policy toolkit critical levers to address problems of high transaction costs and risks inducing market failures." The authors argue for a fundamental reassessment of policies espousing state withdrawal from markets in poor agrarian economies and the search for alternative ways of 'kick starting' markets in ways that promote rather than crowd out private sector investment, and that allow the state to withdraw as economic growth proceeds (Dorward et al. 2004).

While the case studies in Honduras, El Salvador, and Mexico paint a seemingly bleak picture of the ability of the public and private sector to generate sustainable farmer 
organizations among smallholders, they do suggest more appropriate ways forward. Development agencies can play a very important role in facilitating farmer organization development, especially in the early stages, but greater attention has to be directed to the question of 'farmer organization for what purpose.' Another useful question to ask would be: 'once we are organized, who can we partner with?'

The research in Central America identified a promising avenue to explore: the lead farmer models currently under development by the private sector. It is important to note, however, that the Agropyme study (2006) clearly identifies that only the upper tier of smallholders can feasibly participate as lead farmers in such a model. Nonetheless, more organic organizational structures with lower fixed organizational costs might provide a way forward in terms of improved farmer organization.

\section{CONCLUSIONS}

Research in Mexico and Central America has suggested that the benefits of farmer organization when it comes to access output markets are more evident in the vegetable sector, which is characterized by high transaction costs. There is far less incentive for farmers producing a commodity such as maize to organize themselves as the transaction costs associated with market access are relatively low. In El Salvador and Honduras, however, farmer organizations that sell vegetables secure a very small percentage of the final consumer price. Low volumes of product plus low margins mean that ongoing subsidies are probably needed to cover operational costs.

Farmer organization is a critical factor in making input and output markets work, but the role and timing of the substantial public and private investment needed to establish and maintain these organizations remains poorly understood. There is also a need to understand better the costs and margins along the value chain to make sure that the services provided are sustainable once development subsidies dry up. Many organizations do not know how much it costs to provide, for example, technical assistance nor have they incorporated it into their non donor-subsidized cost structures. 
While the political climate over the last two decades has been hostile to subsidies (although the rhetoric is somewhat different from the practice), there is increasing recognition of the key roles that both the private and public sectors can play in contributing to agricultural development. Governments are of central importance in determining how markets should function. Governments, for example, can help ensure that the legal and judicial system supports low-cost contract enforcement (including getting rid of red tape); facilitate the flow of market information through effective communication systems; and make transport, electricity, water and other infrastructure systems widely available in order to help support small enterprises and BDS providers.

Similarly, development agencies can play a very important role in facilitating farmer organization development, especially in the early stages. But greater attention has to be directed at examining the purpose and the appropriate partners of such organization. As we found in Mexico, while there may be very few benefits to producers of commodities organizing for market sales, organizations can still make a contribution to their members, as long as they engage in services other than marketing undifferentiated commodities.

Farmer organizations can play an important role in contributing to poverty reduction and improved livelihood security in Meso-America. However, the issue of public and/or private investment and the use of subsidies to sustain farmer organizations is one that researchers and development practitioners should not shy away from confronting; it is imperative to analyze these issues when decisions are made about where to invest often scarce resources. 


\section{REFERENCES}

Agropyme. 2005. Análisis de la cadena de valor para tomate de mesa, chile dulce, brócoli, lechuga, zanahoria y papa producida por pequeños productores, con enfoque en la comercialización a través de supermercados. Tegucigalpa, Honduras: Agropyme, Agencia Suiza para el Desarrollo y la Cooperación (COSUDE) y Swisscontact,

Agropyme. 2006. Innovaciones Organizacionales de Pequeños Productores de Vegetales para Participar en Canales de Comercialización Dinámicos en Honduras." Report prepared for the Regoverning Markets Consortium. Tegucigalpa, Honduras: Agropyme, Agencia Suiza para el Desarrollo y la Cooperación (COSUDE) y Swisscontact.

Barghouti, S., S. Kane, K. Sorby and M. Ali. 2004. Agricultural diversification for the poor: guidelines for practitioners. Agricultural and Rural Development Discussion Paper 1. Washington, D.C.: World Bank.

Bellon, M.R., M. Adato, J. Becerril, and D. Mindek. 2005. Impact of improved maize germplasm on poverty alleviation: The case of tuxpeño-derived materials in Mexico. México, D.F.: CIMMYT.

Berdegué, J. 2001. Cooperating to Compete - Associative Peasant Business Firms in Chile. PhD. Thesis. Wageningen University, Wageningen, the Netherlands.

Berdegué, J. 2002. Learning to beat Cochrane's treadmill. Public policy, markets and social learning in Chile's small-scale agriculture. In Wheelbarrows full of frogs: Social learning in rural resource management, ed. Leeuwis, C. and R. Pyburn. Wageningen, the Netherlands: Agricultural University of Wageningen

Berdegué, J., T. Reardon, F. Balsevich, L. Flores, and R.A. Hernández. 2007. Supermarkets and small horticultural product farmers in Central America. In Global supply chains, standards and the poor: How the globalization of food systems and standards affects rural development and poverty, ed. Swinnen, J.F.M. Oxford, England: CABI.

Boehlje, M. 1999. Structural changes in the agricultural industries: how do we measure, analyze and understand them? American Journal of Agricultural Economics 81 (5): 1028-1041.

Camacho, P., Marlin, C. and Zambrano, C. 2005. Estudio regional sobre factores de éxito de empresas asociativas rurales. Quito, Ecuador: Ruralter Plataforma Regional Andina.

Catholic Relief Services. 2005. Caso El Salvador. Inserción de pequeños productores a los supermercados bajo el enfoque de cadena agroempresarial con los productos tomate, chile y pepino. Programa de Agricultura. El Salvador, San Salvador: Catholic Relief.

DFID. 2004. What is pro-poor growth and why do we need to know? Pro-Poor Growth Briefing Note. London: DFID. 
DFID. 2005. Making market systems work better for the poor (M4P) - An introduction to the concept. Discussion paper prepared for the ADB-DFID 'learning event' ADB Headquarters, Manila. February 2005. London: DFID.

Dixon, J., A. Gulliver, and D. Gibbon. 2001. Farming systems and poverty. improving farmer's livelihoods in a changing world. Rome, Italy \& Washington D.C.: FAO \& World Bank.

Dorward, A., Kydd, J., Morrison, J. and Urey, I. 2004. A policy agenda for pro-poor agricultural growth. World Development 32(1): 73-89.

Dorward, A., N. Poole, J. Morrison, J. Kydd, and I. Urey. 2003. Markets, institutions and technology: missing links in livelihoods analysis. Development Policy Review 21(3): 319-332.

Echánove, F. and C. Steffen, C. 2005. Agribusiness and farmers in Mexico: the importance of contractual relations. The Geographical Journal 171 (2): 166-176.

Ellis, F. and N. Harris. 2004. 'Development Patterns, Mobility and Livelihood Diversification,' keynote Paper for DFID Sustainable Development Retreat, University of Surrey, Guildford, UK.

Erenstein, O., P. Cadena, R. de la Piedra, and A, Lopez. 1998. Una vez mas, la adopción de la conservación de residuos en La Fraylesca, Chiapas 98-02 Es. Mexico: CIMMYT.

FAO (Food and Agriculture Organization of the United Nations). 2004. The State of Food Insecurity in the World 2004. Annual report by Economic and Social Department. Rome: FAO.

Flores, D., A. Ramirez, and M.R. Bellon. 2004. Characterization of the formal maize seed supply system in the Frailesca region, Chiapas, Mexico. Report to the Agricultural and Development Economics Division (ESA). Rome: FAO.

Gulati A., N. Minot, C. Delgado, and S. Bora. 2007. Growth in high-value agriculture in Asia and the emergence of vertical links with farmers. In (Global Supply chains, standards and the poor: how the globalization of food systems and standards affects rural development and poverty, ed. Swinnen, J.F.M pp. 91-108. Oxford, England: CABI.

Hamilton, S. and E. F. Fischer. 2003. Non-traditional agricultural exports in highland Guatemala: Understandings of risk and perceptions of change. Latin American Research Review 38(3): 82-110.

Hellin, J. and S. Higman. 2003. Feeding the market: South American farmers, trade and globalization. London, UK: ITDG Publishing and Latin American Bureau.

Hellin, J., A. Griffith, and M. Albu. 2005. Mapping the market: market-literacy for agricultural research and policy to tackle rural poverty in Africa. In Beyond agriculture - making markets work for the poor, ed. Almond, F.R. and S.D. Hainsworth. Proceedings of an international seminar, February 28 - March 1, 2005. Westminster, London, UK. Crop Post-Harvest Programme, Natural Resources International Limited and Practical Action, UK.

Hellin, J., M. Lundy, and M. Meijer. 2007. Farmer organization and market access. LEISA Magazine 23 (1):26-27. 
Hitchins, R., D. Elliot, and A. Gibson. 2004. Making business service markets work for the poor in rural areas: a review of experience, report for DFID. Durham, UK.: Springfield Centre.

Hu, D., R. Reardon, S. Rozelle, P. Timmer, and H. Wang. 2004. The emergence of supermarkets with Chinese characteristics: challenges and opportunities for China's agricultural development. Development Policy Review 22(5): 557-586.

Hulme, D. and A. Shepherd. 2003. Conceptualizing chronic poverty. World Development 3 (3): $403-$ 423.

Key, N. and D. Runsten. 1999. Contract farming, smallholders, and rural development in Latin America: The organization of agroprocessing firms and the scale of outgrower production. World Development 27 (2): 381-401.

Kydd, J. 2002. Agriculture and rural livelihoods: is globalisation opening or blocking paths out of rural poverty?' Agricultural Research and Extension Network (AgREN) Paper No. 121. Overseas Development Institute, London, UK.

Long, N. and M. Villarreal. 1998. Small product, big issues: Value contestations and cultural identities in cross-border commodity networks. Development and Change 29: 725-750.

Lundy, et al. 2006. Assessing small-holder participation in value chains: the case of vegetables in Honduras and El Salvador. Colombia: CIAT.

Lundy, M., C. Ostertag, and R. Best. 2002. Value adding, agroenterprise and poverty reduction: A territorial approach for rural business development. Paper presented at Globalization of Agricultural Research conference, February 25-27, 2002. Turrialba, Costa Rica.

Marr, A. 2003. Institutional approaches to the delivery of business development services: a review of recent literature., Kent, England, United Kingdom: Natural Resources Institute.

Masakure, O. and Henson, S. 2005. Why do small-scale producers choose to produce under contract? Lessons from nontraditional vegetable exports from Zimbabwe. World Development 33 (10): $1721-1733$.

Meinzen-Dick, R. and M. Di Gregorio. 2004. Collective action and property rights for sustainable development. 2020 Vision. Focus 11. Brief 1 of 16. Washington, D.C.: International Food Policy Research Institute.

Miehlbradt, A.O. and M. McVay. 2005. From BDS to making markets work for the poor. Geneva, Switzerland: International Labour Organization.

Narayanan, S. and A. Gulati, A. 2002. Globalization and the smallholders: a review of issues, approaches and implications. Markets and Structural Studies Division Discussion Paper no. 50. Washington, D.C.: International Food Policy Research Institute and the World Bank.

ODI (Overseas Development Institute). 2003. Food policy old and new. ODI Briefing Paper November 2003 (unnumbered) London: ODI. 
Pingali, P., Y. Khwaja, and M. Meijer. 2005. Commercializing small farms: Reducing transaction costs. ESA Working Paper No. 05-08. Agricultural and Development Economics Division. Rome: FAO.

Reardon, T. 2005. Retail companies as integrators of value chains in developing countries: Diffusion, procurement system change, and trade and development effects. Eschborn, Germany: GTZ.

Reardon, T. and J. Berdegué, 2002. The rapid rise of supermarkets in Latin America: Challenges and opportunities for development. Development Policy Review 20 (4): 371-388.

Reardon, T. and L. Flores. 2006. 'Customized competitiveness' strategies for horticultural exporters: Central America focus with lessons from and for other regions. Viewpoint Article. Food Policy 31 (6): 483-503.

Rehber, E. 2004. Vertical integration in the food industry in the food industry and contract farming. Outlook on Agriculture 33 (2): 85-91.

Sain, G. y M.A. López-Pereira. 1999. Maize production and agricultural policies in Central America and Mexico. CIMMYT Documento de Trabajo de Economía No. 99-02. México, D.F.: CIMMYT.

Shepherd, A. 2005. The implications of supermarket development for horticultural farmers and traditional marketing systems in Asia. Rome: FAO.

Singh, S. 2005. Contract farming for agricultural development: Review of theory and practice, with special reference to India. CENTAD Working Papers. Ahmedabad, Gujarat, India: Centre for Management in Agriculture, Indian Institute of Management.

Stockbridge, M., A. Dorward, and J. Kydd. 2003. Farmer organizations for market access: A briefing paper. Wye Campus, Kent, England: Imperial College, London.

Stringfellow, R., J. Coulter, T. Lucey, C. McKone and A. Hussain. 1997. Improving the access of smallholders to agricultural services in sub-Saharan Africa: farmer cooperation and the role of the donor community. Natural Resources Perspectives 20. London: Overseas Development Institute. 


\section{List of CAPRi Working Papers}

01 Property Rights, Collective Action and Technologies for Natural Resource Management: A Conceptual Framework, by Anna Knox, Ruth Meinzen-Dick, and Peter Hazell, October 1998.

02 Assessing the Relationships between Property Rights and Technology Adoption in Smallholder Agriculture: A Review of Issues and Empirical Methods, by Frank Place and Brent Swallow, April 2000.

03 Impact of Land Tenure and Socioeconomic Factors on Mountain Terrace Maintenance in Yemen, by A. Aw-Hassan, M. Alsanabani and A. Bamatraf, July 2000.

04 Land Tenurial Systems and the Adoption of a Mucuna Planted Fallow in the Derived Savannas of West Africa, by Victor M. Manyong and Victorin A. Houndékon, July 2000.

05 Collective Action in Space: Assessing How Collective Action Varies Across an African Landscape, by Brent M. Swallow, Justine Wangila, Woudyalew Mulatu, Onyango Okello, and Nancy McCarthy, July 2000.

06 Land Tenure and the Adoption of Agricultural Technology in Haiti, by Glenn R. Smucker, T. Anderson White, and Michael Bannister, October 2000.

07 Collective Action in Ant Control, by Helle Munk Ravnborg, Ana Milena de la Cruz, María Del Pilar Guerrero, and Olaf Westermann, October 2000.

08 CAPRi Technical Workshop on Watershed Management Institutions: A Summary Paper, by Anna Knox and Subodh Gupta, October 2000.

09 The Role of Tenure in the Management of Trees at the Community Level: Theoretical and Empirical Analyses from Uganda and Malawi, by Frank Place and Keijiro Otsuka November 2000.

10 Collective Action and the Intensification of Cattle-Feeding Techniques a Village Case Study in Kenya's Coast Province, by Kimberly Swallow, November 2000.

11 Collective Action, Property Rights, and Devolution of Natural Resource Management: Exchange of Knowledge and Implications for Policy, by Anna Knox and Ruth MeinzenDick, January 2001.

12 Land Dispute Resolution in Mozambique: Evidence and Institutions of Agroforestry Technology Adoption, by John Unruh, January 2001. 
13 Between Market Failure, Policy Failure, and "Community Failure": Property Rights, CropLivestock Conflicts and the Adoption of Sustainable Land Use Practices in the Dry Area of Sri Lanka, by Regina Birner and Hasantha Gunaweera, March 2001.

14 Land Inheritance and Schooling in Matrilineal Societies: Evidence from Sumatra, by Agnes Quisumbing and Keijuro Otsuka, May 2001.

15 Tribes, State, and Technology Adoption in Arid Land Management, Syria, by Rae, J, Arab, G., Nordblom, T., Jani, K., and Gintzburger, G., June 2001.

16 The Effects of Scales, Flows, and Filters on Property Rights and Collective Action in Watershed Management, by Brent M. Swallow, Dennis P. Garrity, and Meine van Noordwijk, July 2001.

17 Evaluating Watershed Management Projects, by John Kerr and Kimberly Chung, August 2001.

18 Rethinking Rehabilitation: Socio-Ecology of Tanks and Water Harvesting in Rajasthan, North-West India, by Tushaar Shah and K.V.Raju, September 2001.

19 User Participation in Watershed Management and Research, by Nancy Johnson, Helle Munk Ravnborg, Olaf Westermann, and Kirsten Probst, September 2001.

20 Collective Action for Water Harvesting Irrigation in the Lerman-Chapala Basin, Mexico, by Christopher A. Scott and Paul Silva-Ochoa, October 2001.

21 Land Redistribution, Tenure Insecurity, and Intensity of Production: A Study of Farm Households in Southern Ethiopia, by Stein Holden and Hailu Yohannes, October 2001.

22 Legal Pluralism and Dynamic Property Rights, by Ruth Meinzen-Dick and Rajendra Pradhan, January 2002.

23 International Conference on Policy and Institutional Options for the Management of Rangelands in Dry Areas, by Tidiane Ngaido, Nancy McCarthy, and Monica Di Gregorio, January 2002.

24 Climatic Variablity and Cooperation in Rangeland Management: A Case Study From Niger, by Nancy McCarthy and Jean-Paul Vanderlinden, September 2002.

25 Assessing the Factors Underlying the Differences in Group Performance: Methodological Issues and Empirical Findings from the Highlands of Central Kenya, by Frank Place, Gatarwa Kariuki, Justine Wangila, Patti Kristjanson, Adolf Makauki, and Jessica Ndubi, November 2002. 
The Importance of Social Capital in Colombian Rural Agro-Enterprises, by Nancy Johnson, Ruth Suarez, and Mark Lundy, November 2002.

27 Cooperation, Collective Action and Natural Resources Management in Burkina Faso: A Methodological Note, by Nancy McCarthy, Céline Dutilly-Diané, and Boureima Drabo, December 2002.

28 Understanding, Measuring and Utilizing Social Capital: Clarifying Concepts and Presenting a Field Application from India, by Anirudh Krishna, January 2003.

29 In Pursuit Of Comparable Concepts and Data, about Collective Action, by Amy Poteete And Elinor Ostrom, March 2003.

30 Methods of Consensus Building for Community Based Fisheries Management in Bangladesh and the Mekong Delta, by Parvin Sultana and Paul Thompson, May 2003.

31 Formal and Informal Systems in Support of Farmer Management of Agrobiodiversity: Some Policy Challenges to Consolidate Lessons Learned, by Marie Byström, March 2004.

32 What Do People Bring Into the Game: Experiments in the Field About Cooperation in the Commons, by Juan-Camilo Cárdenas and Elinor Ostrom, June 2004.

33 Methods for Studying Collective Action in Rural Development, by Ruth Meinzen-Dick, Monica Di Gregorio, and Nancy McCarthy, July 2004.

34 The Relationship between Collective Action and Intensification of Livestock Production: The Case of Northeastern Burkina Faso, by Nancy McCarthy, August 2004.

35 The Transformation of Property Rights in Kenya's Maasailand: Triggers and Motivations by Esther Mwangi, January 2005.

36 Farmers' Rights and Protection of Traditional Agricultural Knowledge, by Stephen B. Brush, January 2005.

37 Between Conservationism, Eco-Populism and Developmentalism - Discourses in Biodiversity Policy in Thailand and Indonesia, by Heidi Wittmer and Regina Birner, January 2005.

38 Collective Action for the Conservation of On-Farm Genetic Diversity in a Center of Crop Diversity: An Assessment of the Role of Traditional Farmers' Networks, by Lone B. Badstue, Mauricio R. Bellon, Julien Berthaud, Alejandro Ramírez, Dagoberto Flores, Xóchitl Juárez, and Fabiola Ramírez, May 2005.

39 Institutional Innovations Towards Gender Equity in Agrobiodiversity Management: Collective Action in Kerala, South India,, by Martina Aruna Padmanabhan, June 2005. 

and Biodiversity from Legal Pluralism, by Melanie G. Wiber, July 2005.

41 Who Knows, Who Cares? Determinants of Enactment, Awareness and Compliance with Community Natural Resource Management Bylaws in Uganda, by Ephraim Nkonya, John Pender, Edward Kato, Samuel Mugarura, and James Muwonge, August 2005.

42 Localizing Demand and Supply of Environmental Services: Interactions with Property Rights, Collective Action and the Welfare of the Poor, by Brent Swallow, Ruth MeinzenDick, and Meine von Noordjwik, September 2005.

43 Initiatives for Rural Development through Collective Action: The Case of Household Participation in Group Activities in the Highlands of Central Kenya, By Gatarwa Kariuki and Frank Place, September 2005.

44 Are There Customary Rights to Plants? An Inquiry among the Baganda (Uganda), with Special Attention to Gender, by Patricia L. Howard and Gorettie Nabanoga, October 2005.

45 On Protecting Farmers' New Varieties: New Approaches to Rights on Collective Innovations in Plant Genetic Resources by Rene Salazar, Niels P. Louwaars, and Bert Visser, January 2006.

46 Subdividing the Commons: The Politics of Property Rights Transformation in Kenya's Maasailand, by Esther Mwangi, January 2006.

47 Biting the Bullet: How to Secure Access to Drylands Resources for Multiple Users, by Esther Mwangi and Stephan Dohrn, January 2006.

48 Property Rights and the Management of Animal Genetic Resources, by Simon Anderson and Roberta Centonze, February 2006.

49 From the Conservation of Genetic Diversity to the Promotion of Quality Foodstuff: Can the French Model of 'Appellation d'Origine Contrôlée' be Exported? by Valérie Boisvert, April 2006.

50 Facilitating Collective Action and Enhancing Local Knowledge: A Herbal Medicine Case Study in Talaandig Communities, Philippines, by Herlina Hartanto and Cecil Valmores, April 2006.

51 Water, Women and Local Social Organization in the Western Kenya Highlands, by Elizabeth Were, Brent Swallow, and Jessica Roy, July 2006.

52 The Many Meanings of Collective Action: Lessons on Enhancing Gender Inclusion and Equity in Watershed Management, by Laura German, Hailemichael Taye, Sarah Charamila, Tesema Tolera, and Joseph Tanui, July 2006. 
53 Decentralization and Environmental Conservation: Gender Effects from Participation in Joint Forest Management, by Arun Agrawal, Gautam Yadama, Raul Andrade, and Ajoy Bhattacharya, July 2006.

54 Improving the Effectiveness of Collective Action: Sharing Experiences from Community Forestry in Nepal, by Krishna P. Achyara and Popular Gentle, July 2006.

55 Groups, Networks, and Social Capital in the Philippine Communities, by Marie Godquin and Agnes R. Quisumbing, October 2006.

56 Collective Action in Plant Genetic Resources Management: Gendered Rules of Reputation, Trust and Reciprocity in Kerala, India, by Martina Aruna Padmanabhan, October 2006.

57 Gender and Local Floodplain Management Institutions--A case study from Bangladesh, by Parvin Sultana and Paul Thompson, October 2006.

58 Gender Differences in Mobilization for Collective Action: Case Studies of Villages in Northern Nigeria, by Saratu Abdulwahid, October 2006.

59 Gender, Social Capital and Information Exchange in Rural Uganda, by Enid Katungi, Svetlana Edmeades, and Melinda Smale, October 2006.

60 Rural Institutions and Producer Organizations in Imperfect Markets: Experiences from Producer Marketing Groups in Semi-Arid Eastern Kenya, by Bekele Shiferaw, Gideon Obare and Geoffrey Muricho, November 2006.

61 Women's Collective Action and Sustainable Water Management: Case of SEWA's Water Campaign in Gujarat, India, by Smita Mishra Panda, October 2006.

62 Could Payments for Environmental Services Improve Rangeland Management inCentral Asia, West Asia and North Africa? by Celine Dutilly-Diane, Nancy McCarthy, Francis Turkelboom, Adriana Bruggeman, James Tiedemann, Kenneth Street and Gianluca Serra, January 2007.

63 Empowerment through Technology: Gender Dimensions of Social Capital Build-Up in Maharashtra, India, by Ravula Padmaja and Cynthia Bantilan, February 2007.

64 Gender and Collective Action: A Conceptual Framework for Analysis, by Lauren Pandolfelli, Ruth Meinzen-Dick, and Stephan Dohrn, May 2007.

65 Gender, Wealth, and Participation in Community Groups in Meru Central District, Kenya, by Kristin E. Davis and Martha Negash, May 2007.

66 Beyond Group Ranch Subdivision: Collective Action for Livestock Mobility, Ecological Viability, and Livelihoods, by Shauna BurnSilver and Esther Mwangi, June 2007. 